\title{
Product evaluation based in the association between intuition and tasks
}

\author{
Caio Márcio Almeida e Silva ${ }^{\mathrm{a}, *}$, Maria Lúcia L. R. Okimoto ${ }^{\mathrm{b}}$, Deise Albertazzi ${ }^{\mathrm{c}}$, Cyntia Calixto ${ }^{\mathrm{d}}$, \\ Humberto Costa ${ }^{\mathrm{e}}$ \\ ${ }^{a}$ Design Department, Universidade Federal do Paraná, caiomarcio1001@yahoo.com.br, Rua General Carneiro \\ 460, Edificio Dom Pedro I, $8^{\text {th }}$ andar, Curitiba - PR, Brazil. \\ ${ }^{\mathrm{b}}$ Mechanical Engineering Department, Universidade Federal do Paraná, lucia.demec@ufpr.br, Centro \\ Politécnico, Jardim das Américas, Curitiba - PR, Brazil. \\ ${ }^{\mathrm{c}}$ Design Department, Universidade Federal do Paraná, dalbertazzig@gmail.com, Rua General Carneiro \\ 460Edificio Dom Pedro I, $8^{\text {th }}$ andar, Curitiba - PR, Brazil. \\ d Mechanical Engineering Department, Universidade Federal do Paraná, cyntia@ufpr.br, Centro Politécnico, \\ Jardim das Américas, Curitiba - PR, Brazil. \\ ${ }^{\mathrm{e}}$ Centro Universitário de Curitiba, humbertoccosta@gmail.com, Curitiba-PR, Brazil.
}

\begin{abstract}
This paper explores the importance of researching the intuitiveness in the product use. It approaches the intuitiveness influence for users that already had a visual experience of the product. Finally, it is suggested the use of a table that relates the tasks performed while using a product, the features for an intuitive use and the performance metric "task success".
\end{abstract}

Keywords: intuitiveness, task success, use evaluation.

\section{Introduction and literature review}

The use of intuitiveness in the design field has being explored by many approaches, as theoretical (Norman, 2010; Bürdek, 2006), associating the product development to the intuition (Rutter, Becka and Jenkins, 1997; Frank and Cushcieri, 1997) and exploring usability tests (Blackler, Popovic and Mahar, 2003; Silva and Okimoto, 2011). In the following sections it is presented some approaches relating design and intuition: non-intentional design, natural interaction, archetypes based identification and intuitive use.

This paper approaches the intuition using some aspects included in the research "Intuitiveness in the product use" (Silva and Okimoto, 2011). These aspects will be associated to the tasks and to the task success. An evaluation will assist identifying the influence of the these aspects to the task completion.

\subsection{Aspects for an intuitive use}

The aspects for an intuitive use are those visual elements that influence the product development process. They came from the visual techniques from Dondis (2001), user attention modes from Krippendorff (2006), aspects of the visual appearance of objects from Nefs (2008), universal design principles from Lidwell, Holden and Jill (2010) and principles for usability understanding from Norman (2006).

The terms used below were selected by researches and designers of the appliance industry. They emphasize the intuitiveness of use, as described by Silva (2011). The following table presents these terms:

\footnotetext{
* Author mailing address: caiomarcio1001@yahoo.com.br
} 
Table 1: Conceptualizing the aspects for an intuitive use.

\begin{tabular}{|c|c|}
\hline Aspect & Concept \\
\hline Affordance & $\begin{array}{l}\text { The affordance theory was develop by } \\
\text { Gibson (1979 and 1986) from the percep- } \\
\text { tion of the ecology. Gibson explains that } \\
\text { the affordance of the environment is what } \\
\text { the environment offers to an animal. It } \\
\text { implies the complementarity between the } \\
\text { animal and the environment. The term was } \\
\text { used on further studies from Lidwell et al } \\
\text { (2010), Krippendorff (2006) and Norman } \\
(2006 \text { and 2010). }\end{array}$ \\
\hline Attractiveness & $\begin{array}{l}\text { Attractiveness is a relative quality that only } \\
\text { exists if there is a contrast between some- } \\
\text { thing that catches attention and something } \\
\text { that does not call attention, according to } \\
\text { Krippendorff (2006). The author presents } \\
\text { also some contrasts used in the design field. } \\
\text { They are used as tools for communicating } \\
\text { with the product: news, in right place, } \\
\text { simplicity, unity, regularity, symmetry, } \\
\text { equilibrium, in/out the grid and intentional- } \\
\text { ity. }\end{array}$ \\
\hline Color & $\begin{array}{l}\text { Colors are used in the design to catch the } \\
\text { attention of people, according to Lidwell, } \\
\text { Holden and Jill ( } 2010) \text {. They may also } \\
\text { assist explaining things, aesthetically } \\
\text { compose a product, or integrate the ele- } \\
\text { ments of the product interface. The design- } \\
\text { er has to care about the possible combina- } \\
\text { tions, harmonies, contrasts, saturation and } \\
\text { their symbolism. }\end{array}$ \\
\hline $\begin{array}{l}\text { Aesthetic / usability } \\
\text { effect }\end{array}$ & $\begin{array}{l}\text { The aesthetic phenomenon occurs when } \\
\text { people realize that aesthetical pleasing } \\
\text { products are easier to use than not aestheti- } \\
\text { cal pleasing products, this effect being } \\
\text { associated to the usability (Lidwell, Holden } \\
\text { and Jill, 2010). The aesthetical pleasing } \\
\text { products are more effective as they pro- } \\
\text { mote positive attitudes, as described by the } \\
\text { authors. }\end{array}$ \\
\hline Errors & $\begin{array}{l}\text { An error is an "action or omission that } \\
\text { produces non intentional results" (Lidwell, } \\
\text { Holden and Jill, 2010, translated by the } \\
\text { authors). Studying the origins of the errors } \\
\text { may help understanding which design } \\
\text { strategies help reduce their frequency and } \\
\text { severity. An error might be from a slip or a } \\
\text { mistake kind, according to Lidwell et al } \\
(2010) \text {. }\end{array}$ \\
\hline Closing & $\begin{array}{l}\text { Lidwell, Holden and Jill (2010) presents } \\
\text { the closing as a trend to realize and recog- } \\
\text { nize a set of distinct elements that creates a } \\
\text { pattern, these elements not being perceived } \\
\text { individually. }\end{array}$ \\
\hline Feedback & $\begin{array}{l}\text { A feedback provides the user with the } \\
\text { return of information about a performed } \\
\text { action (NORMAN, 2006). It is important to } \\
\text { help understanding the outcome of our } \\
\text { action while using a product: if the task }\end{array}$ \\
\hline
\end{tabular}

was performed or the reason it was not possible to finish it.

\begin{tabular}{|c|c|}
\hline Legibility & $\begin{array}{l}\text { Legibility is the visual distinctness of the } \\
\text { text, based on factors as size, typography, } \\
\text { contrast, text blocks, and the spacing be- } \\
\text { tween the characters (Lidwell, Holden and } \\
\text { Jill, 2010). It is widely used in the graphic } \\
\text { design field, but may also be used in the } \\
\text { product design when providing non legible } \\
\text { graphical information on a product inter- } \\
\text { face or when some functions are not easily } \\
\text { discovered by the user. }\end{array}$ \\
\hline
\end{tabular}

\begin{tabular}{ll}
\hline Desire line & The desire line represent evidences that \\
help identifying the kind of interaction and \\
possible methods used for that. These evi- \\
dences of use indicate the frequency of use \\
in the context, being important to consider \\
them while in the product development \\
process (Lidwell, Holden and Jill, 2010). \\
Some researches consider the desire line in \\
computer interfaces by tracking the user \\
eyes or mouse movements. These proce- \\
dures help identifying the most viewed \\
areas of the interface, being possible to use \\
this knowledge to help developing other \\
interfaces. \\
Tracking is the relation between the con- \\
trols / movements and their effects. A well \\
made tracking helps the ease of use of a \\
product. The tracking might be of three \\
kinds: similar layouts (e.g., the controls of \\
an oven and its burners placed in the same \\
order), similar movements (e.g., the \\
movement of a steering wheel and the \\
direction of a car) and similar meanings \\
(e.g., a color symbolism and an emergency \\
control) (Lidwell, Holden and Jill, 2010). \\
The metonymies are pieces chosen to \\
represent the group from which they belong \\
(KRIPPENDORFF, 2006). Some social \\
stereotypes are metonymies that represent a \\
group of people, e.g., a group of single \\
people or a group of vegetarians, as de- \\
scribed by the author. The metonymies are \\
cognitive paths, related to the meaning and \\
significance a product represents to the \\
observer.
\end{tabular}

Conceptual models A conceptual model is a map of operational concepts that helps the user understand how a product works, how the user is supposed to interact with the product and the consequence of the interactions made with the product [Lakoff (1987 apud KRIPPENDORFF , 2006)]. It is common to relate the recognition of concept models to experiences the user brings to the product (KRIPPENDORFF, 2006). According to Norman (2006), a good conceptual model allows people to predict the effects of their actions.

Mental model Previous interactions with systems and


environments help people create mental representations based in their experiences. There are two kinds of mental models in the design field: based in operating systems (system model) and based in the interaction between people and systems (interaction model), as described by Lidwell, Holden and Jill (2010). According to Norman (2006), mental models are created based in experiences, trainings and instructions, being build from the interpretation of actions taken and visible structures of the products.

\begin{tabular}{ll}
\hline Motivations & Motivations are justifications for certain \\
actions. They might be extrinsic, when the \\
actions are justified by the achieved goals, \\
or intrinsic, when the actions are justified \\
by themselves (KRIPPENDORFF, 2006). \\
\hline Entrance point & The entrance point is a physical entrance or \\
& an attention point in the design for a system \\
that might be a tridimensional product, a & graphic material or a construction (LID- \\
& WELL et al, 2010). The main elements for \\
& a good entrance point design are: minimal \\
barriers, perspective points that let the user \\
clearly see all the product/environment, and \\
progressive attractions to catch people \\
attention for the entrance point (Lidwell, \\
Holden and Jill, 2010). \\
\hline Restrictions are ways to restrict the possi- \\
ble actions that might be performed with a \\
system. They also help restrict the errors, \\
as explained by Lidwell, Holden and Jill \\
(2010).
\end{tabular}

Silva and Okimoto (2011)

\section{Methodological formulation}

The chosen product for the test was a wireless presenter for computers (Figure 1). A task analysis was made, followed by the development of tools for evaluating the usability tests. The test was made individually with ten participants of a group of professors and post-graduate students from the Universidade Federal do Paraná. The wireless presenter was introduced for each participant and a visual scheme of the product functions was given. The participants were asked to read the tasks instructions loudly before having them performed and to verbalize their mental processes while performing the tasks.

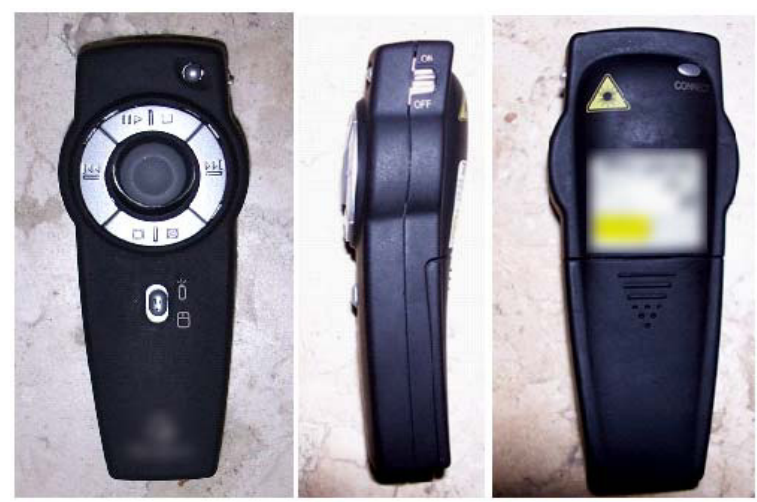

Figure 1: Wireless presenter (photo of Humberto Costa)
The data was collected by using a table relating the tasks, task success, the aspects for an intuitive use, the aspects success and the need the participants had to search for help in the visual scheme of the product functions. The intuition aspects were measured based on the performance metrics from the usability test and by using the verbalization and observation techniques.

\section{Experiment}

The experiment was made in three stages: discovering expectations, tasks realization and product evaluation.

On the first stage the researches introduced the product to the participants by using a slide presentation, the visual scheme of the product functions and the product itself. The participants were given a form and were asked if they knew the product before, if they have used it before and their expectations about the product.

On the second stage, the participants were asked to perform a given list of tasks, first reading loudly 
each one and than trying to perform it. The 17 tasks were the following:

1. Plug the receiver into the computer (USB port)

2. Turn the wireless presenter on

3 . Turn the receiver on until the green light lights on it (to synchronize)

4. Push the "connect" button in the presenter until the green light from the receptor turned off (to synchronize)

5. Activate the mouse function

6. Open the "Bionics" presentation

7. Open the presentation in the full screen mode

8 . Activate the presenter function

9. Point the laser at the black banner that is in front

10. Advance the presentation until the "Example: lotus effect (video)" slide

11. Active the mouse function when in the "Example: lotus effect (video)" slide

12. Click in the photo from the "Example: lotus effect (video)" slide to activate the video, advancing to the next task when it starts

13. Activate the presenter function

14. Point the laser at the black banner that is in front

15. Advance the slides to the end of the presentation

16. Activate the mouse function

17. Close the program and notify that the tasks were ended

The third stage is the after use evaluation, aimed in obtaining the user perceptions about the product usability. The participants were asked to choose three adjectives to represent the product from a list of 56 adjectives. Finally, each participant assigned an usability score for the product from zero to ten.

This paper explores mainly the second stage. The data was collected by using the table presented bellow. No analysis was made for the items $6,7,9,14$ and 17 , as they involve the computer software interface and not the product interface.

Table 2

Task analysis related to the intuitive use

\begin{tabular}{|c|c|c|c|c|c|}
\hline & Tasks & $\begin{array}{l}\text { Task } \\
\text { success }\end{array}$ & $\begin{array}{l}\text { Aspects for an intuitive } \\
\text { use }\end{array}$ & $\begin{array}{l}\text { Aspects } \\
\text { success }\end{array}$ & $\begin{array}{l}\text { Search for visual } \\
\text { scheme }\end{array}$ \\
\hline 1 & $\begin{array}{l}\text { Plug the receiver into the computer } \\
\text { (USB port) }\end{array}$ & 10 & $\begin{array}{l}\text { Conceptual model } \\
\text { Iconic representation }\end{array}$ & $\begin{array}{c}10 \\
0\end{array}$ & 0 \\
\hline 2 & Turn the wireless presenter on & 8 & Affordance & 1 & 6 \\
\hline 3 & $\begin{array}{l}\text { Turn the receiver on until the green } \\
\text { light lights on it (to synchronize) }\end{array}$ & 10 & $\begin{array}{l}\text { Visibility } \\
\text { Feedback }\end{array}$ & $\begin{array}{l}10 \\
10\end{array}$ & 2 \\
\hline 4 & $\begin{array}{l}\text { Push the "connect" button in the pre- } \\
\text { senter until the green light from the } \\
\text { receptor turned off (to synchronize) }\end{array}$ & 10 & Legibility & 1 & 3 \\
\hline 5 & Activate the mouse function & 9 & Iconic representation & 8 & 2 \\
\hline 6 & Open the "Bionics" presentation & 10 & $\begin{array}{l}----- \\
---\end{array}$ & $\begin{array}{ll}------ \\
---\end{array}$ & 0 \\
\hline 7 & $\begin{array}{l}\text { Open the presentation in the full screen } \\
\text { mode }\end{array}$ & 10 & -------- & -------- & 0 \\
\hline 8 & Activate the presenter function & 10 & Iconic representation & 9 & 1 \\
\hline 9 & $\begin{array}{l}\text { Point the laser at the black banner that } \\
\text { is in front }\end{array}$ & 10 & -------- & ------- & 2 \\
\hline 10 & Advance the presentation until the "Ex- & 10 & Iconic representation & 7 & 3 \\
\hline
\end{tabular}




\begin{tabular}{|c|c|c|c|c|c|}
\hline & ample: lotus effect (video)" slide & & & & \\
\hline 11 & $\begin{array}{l}\text { Active the mouse function when in the } \\
\text { "Example: lotus effect (video)" slide }\end{array}$ & 10 & Iconic representation & 9 & 1 \\
\hline 12 & $\begin{array}{l}\text { Click in the photo from the "Example: } \\
\text { lotus effect (video)" slide to activate the } \\
\text { video, advancing to the next task when } \\
\text { it starts }\end{array}$ & 10 & ------- & ------- & 2 \\
\hline 13 & Activate the presenter function & 10 & Iconic representation & 10 & 0 \\
\hline 14 & $\begin{array}{l}\text { Point the laser at the black banner that } \\
\text { is in front }\end{array}$ & 10 & 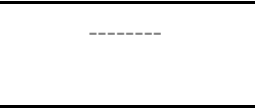 & $\begin{array}{ll}---- \\
----\end{array}$ & 0 \\
\hline 15 & $\begin{array}{l}\text { Advance the slides to the end of the } \\
\text { presentation }\end{array}$ & 10 & Iconic representation & 10 & 0 \\
\hline 16 & Activate the mouse function & 10 & Iconic representation & 10 & 0 \\
\hline 17 & $\begin{array}{l}\text { Close the program and notify that the } \\
\text { tasks were ended }\end{array}$ & 10 & $\begin{array}{l}----- \\
---1\end{array}$ & $\begin{array}{ll}------ \\
---\end{array}$ & 0 \\
\hline Total & & 107 & & 80 & 18 \\
\hline
\end{tabular}

Most of the aspects for an intuitive use were from the iconic representation kind in the researched product. The success score of the iconic representation started at zero (first task), raising in the following tasks, as the participant required the continuous identification of the aspect. This phenomenon might be described by the learnability and by the location of the iconic representation / function in the product.

The task success column from Table 2 was obtained by adding the number of participants that concluded the task with success. Excepting the items 6, 7, 9, 14 and 17, as explained above, the total amount was 107.

The aspects success column scored the times the aspects directly helped the participant performing the task with success. The tasks numbered 1 and 3 there are two aspects, being made the mean to obtain the number to be used in the sum. The total amount was 80 . The number of times the participant searched for help using the visual scheme was subtracted from the total amount, as the search implies that the product is not as intuitive as it should be. The final amount obtained was 62 .

The relation between the task success and the number of task resulted in a 57,8\% rate of success in the task realization. This success rate was based on the aspects for an intuitive use and other aspects as context and previous experiences of the participant.
Based on the described results, two comparisons were realized. They related the task success and the total tasks number to the final success for the aspects for an intuitive use number. On both cases it was realized a rule of three to verify the percentages.

On the first case, around 57,8\% of the task success, among other factors (i.e. repertory and context), occurs because the use of the aspects for an intuitive use. On the second case, for around $56,4 \%$ of the total tasks number, the aspects for an intuitive use were positive.

Even that the percentages might be similar, they reveal the lack of well using the aspects for an intuitive use on the project of a product. While associating these low percentages to the negative comments made during the verbalization and after-task evaluation, it is revealed that the product has badly applied elements from its interface that lead to an intuitive use.

\section{Conclusion}

The paper explored the importance of researching the intuition related to the product use. It was analyzed the influence of the intuitiveness for users that already had a quick visual experience with the product. It was used a table relating the tasks and the as- 
pects for an intuitive use and the performance metric "task success".

It is concluded that the product used in the test was not a good product to be used along the table, as it has many tasks related to the same aspect for an intuitive use: the iconic representation. Some tasks were related to the computer software interface and not to the product itself. The use of the presented table might be implemented in the product development process. This way, it would be possible to evaluate the intuitiveness even in the prototype phase.

As a suggestion, the weight attribution for the aspects for an intuitive use might improve the measurement process. Furthermore, it is suggested that future works might use other genres of product evaluation.

\section{References}

[1] R. Arnheim. Arte e percepção visual, Nova versão, São Paulo, Pioneira, 2005.

[2] A. V. Cardello and P. M. Wise. Taste, smell and chemesthesis in product experience, In: Product Experience, Oxford: Elsevier (2008)

[3] W. Cybis and A. Bertiol. Ergonomia e usabilidade: conhecimentos, métodos e aplicações. São Paulo, Novatec Editora, 2007.

[4] D. A. Dondis. Sintaxe da linguagem visual. $2^{a}$ edição. São Paulo, Martins Fontes, 1997.

[5] K. Krippendorff. The semantic turn. Boca Raton, Taylor \& Francis Group, 2006

[6] L. Lidwell, K. Holden. B. Jill. Princípios Universais do Design. Porto Alegre, Bookman, 2010.

[7] H. T. Neefs. On the visual appearance of objects. In: Product Experience. Oxford, Elsevier, 2008.

[8] J. Nielsen. Usability engineering. Boston, Academic Press, 1993.

[9] D. A. Norman. O Design do dia-a-dia. Rio de janeiro, Rocco, 2006.

[10] H. N J. Schipperstein and P. Hekkert. Product Experience. Elsevier, 2008

[11] H. N J. Schipperstein; M. P. H. D. Cleiren. Capturing product experiences: a split-modality approach. In: Acta Psychologica 118. Elsevier, p. 293-318, 2005.

[12] C. M. A. Silva, M. R. L. Okimoto. Intuitividade no uso de produtos: proposição de um procedimento de avaliação no âmbito do design. Projeto de pesquisa. Curitiba, 2011.

[13] M. H. Sonneveld and H. N. J. e SCHIFFERSTEIN, H. N. J. The tactual experience of objects. In: Product Experience. Oxford: Elsevier, 2008.

[14] R. Van EgmondVAN. The experience of product sounds. In: Product Experience, Oxford: Elsevier, (2008).

[15] M. Van Hout. (2004). Interactive Products and User Emotions. Dissertação de mestrado. Twente.

[16] M. Van Hout. Interactive Products and User Emotions. Dissertação de mestrado. Twente.

[17] Princípios de Forma e Desenho. São Paulo: Editora Martins Fontes.

[18] M. Wong. Princípios de Forma e Desenho. São Paulo: Editora Martins Fontes.
[19] Silva, C. M. AL; Okimoto,M. L. Intuitividade no uso de produtos: procedimento de avaliação da experiência com o produto no design. Projeto de Pesquisa (mestrado em design), Progama de pós-Graduação em Design, Universidade Federal do Paraná, Curitiba, 2011

[20] C. M. A. e Silva and M. L. Okimoto. Considerando a intuição no uso de produtos. In: Anais do $11^{\circ}$ Congresso Internacional de Ergonomia e Usabilidade de interfaces humano-tecnologia: produtos, informações, ambiente construído e transporte. Manaus, 2011. 